\title{
The Mannheim Cord Blood Bank: Experiences and Perspectives for the Future
}

\author{
Stephanie Lauber Monika Latta Harald Klüter Michael Müller-Steinhardt \\ Institute of Transfusion Medicine and Immunology, Medical Faculty Mannheim, Heidelberg University, \\ Red-Cross Blood Service of Baden-Wuerttemberg - Hessen, Mannheim, Germany
}

\section{Key Words}

Cord blood · Cord blood processing ·

Stem cell transplantation $\cdot$ Hematopoietic stem cells

\section{Summary}

Background and Methods: As a source of hematopoietic stem cells, cord blood (CB) is an alternative to bone marrow or peripheral blood stem cells (PBSC). The Mannheim Cord Blood Bank has currently stored about 1,750 allogeneic CB units. Here we report our experiences and discuss future perspectives of $\mathrm{CB}$ banking. We analyzed $\mathrm{CB}$ units for nucleated cell $(\mathrm{NC})$, mononucleated cell (MNC) and CD34+ cell count, volume, colony-forming units (CFU-GM) as well as ethnic background of the donor. Transplanted CB units were analyzed for patient and transplant characteristics and compared to stored CB units. Results: Only $25 \%$ of all collected CB units met storage criteria. Main reasons for exclusion were: i) insufficient volume $(57.7 \%)$, ii) delayed arrival at the processing site $(19.2 \%)$ and $\mathrm{iii}$ ) little cell count $(7.2 \%)$. Up to now 36 CB units have been released for transplantation mainly to children (62\%). Transplant indications were hematological diseases, immune deficiencies and metabolic diseases. Transplanted CB units showed significantly higher cell counts compared to stored units (NC: 12.5 vs. $7.2 \times 10^{8}$, MNC: 4.7 vs. $2.9 \times 10^{8}$, CD34+ cells: 3.3 vs. $1.8 \times 10^{6}$, mean; $p$ $<0.001$ each) and were found more often in ethnic minority groups ( 36 vs. $20 \%$; $p=0.04$ ). Conclusions: Even though cell count and volume are key parameters for the eligibility of CB units, our data indicate that the ethnic background of the donor also plays a major role. Collection and processing of CB should be optimized in order to gain maximum volume and cell counts.

\section{Schlüsselwörter}

Nabelschnurblut · Nabelschnurblut-Aufarbeitung • Stammzelltransplantation · Hämatopoetische Stammzellen

\section{Zusammenfassung}

Hintergrund und Methoden: Nabelschnurblut (CB) ist eine Alternative zur Gewinnung von hämatopoetischen Stammzellen aus Knochenmark oder peripheren Stammzellen. Die Mannheimer Nabelschnurblutbank hat bisher 1750 allogene Nabelschnurblutpräparate eingelagert. Wir berichten über unsere Erfahrungen und diskutieren Zukunftsperspektiven der Nabelschnurbluteinlagerung. Folgende CB-Parameter wurden untersucht: Volumen, nukleäre (NC), mononukleäre (MNC) und CD34+ Zellen, Kolonie bildende Einheiten (CFUGM) sowie ethnische Herkunft des Spenders. Bei den transplantierten Präparaten wurden die Patienten- und Transplantatdaten ausgewertet und die Präparateeigenschaften mit eingelagerten $C B$ verglichen. Ergebnisse: Nur 25\% aller gesammelten Nabelschnurblutpräparate erfüllten die Einlagerungskriterien. Die Hauptursachen hierfür waren 1) zu niedriges Vollblutvolumen $(57,7 \%), 2)$ zu spätes Eintreffen der Präparate im Verarbeitungszentrum $(19,2 \%)$ sowie 3 ) zu niedrige Zellzahl (7,2\%). Bisher wurden 36 Mannheimer Nabelschnurblutpräparate, vorwiegend an Kinder (62\%) abgegeben. Die Transplantationsindikationen waren primär hämatologische Erkrankungen, Erkrankungen des Immunsystems und metabolische Erkrankungen. Die Zellzahlen der transplantierten Präparate waren signifikant höher, als die der eingelagerten (NC: 12,5 vs. $7,2 \times 10^{8}$, MNC: 4,7 vs. $2,9 \times 10^{8}$, CD34+Zellen: 3,3 vs. $1,8 \times 10^{6}$, Mittelwert; jeweils $\left.p<0,001\right)$. Bei den Spendern der transplantierten Präparate fanden wir bei $36 \%$ einen Migrationshintergrund gegenüber $20 \%$ bei den eingelagerten Präparaten $(p=0,04)$. Schlussfolgerungen: Obwohl vor allem das Volumen und der Zellgehalt für die Auswahl von Nabelschnurblutpräparaten verantwortlich sind, zeigen unsere Daten, dass dabei auch der ethnische Hintergrund der Spender eine bedeutende Rolle spielt. Um Nabelschnurblutpräparate mit einem möglichst großen Volumen und einem hohen Zellgehalt zu gewinnen, müssen die Sammel- und Verarbeitungsmethoden optimiert werden.

\begin{tabular}{ll}
\hline KARGER & @ 2010 S. Karger GmbH, Freiburg \\
$\begin{array}{l}\text { Fax +497614520714 } \\
\text { Information@Karger.de } \\
\text { www.karger.com }\end{array}$ & $\begin{array}{l}\text { Accessible online at: } \\
\text { www.karger.com/tmh }\end{array}$
\end{tabular}




\section{Introduction}

Cord blood (CB) as a source of hematopoietic stem cells in clinical application has proved to be a valuable alternative to bone marrow or peripheral blood stem cell (PBSC) transplantation. It is a curative option for many hematologic malignancies and genetic diseases [1-6]. Although there are about 13 million registered stem cell donors worldwide (source: Bone Marrow Donors Worldwide (BMDW), September 2009), it is still not possible to find a suitable donor for approximately one third of patients in need of a transplant [7]. Using cryopreserved $\mathrm{CB}$ as an additional pool for hematopoietic stem cells has considerably increased the probability to find a suitable transplant for the patients. Another major advantage of $\mathrm{CB}$ is the immediate availability for high-risk patients [8]. More than 20,000 allogeneic cord blood transplantations have been performed since the first CB transplantation in 1988 [9]. Generally, the collection can be performed with the placenta either in utero or ex utero or in deliveries by cesarean section. At present, approximately 400,000 CB units are stored in more than $50 \mathrm{CB}$ banks worldwide [10].

The Cord Blood Bank Mannheim was established in 1996 at the Mannheim Institute of the German Red Cross Blood Service Baden-Wuerttemberg - Hessen, now being part of the 'Deutsche Stammzellspenderdatei' (German Stem Cell Donor Registry). We exclusively store voluntarily donated CB units (at present $\mathrm{n}=1,750$ ) for allogeneic transplantation that have been collected at 7 hospitals in south-western Germany and reported to the German National Bone Marrow Donor Registry (Zentrales Knochenmarkspender-Register Deutschland; ZKRD) in Ulm and to NetCord for worldwide distribution.

Here we report our experiences with collecting and processing of $\mathrm{CB}$ and discuss future perspectives of $\mathrm{CB}$ storage. We evaluated all $\mathrm{CB}$ units that were collected between the foundation of the Cord Blood Bank Mannheim in 1996 and June 2009. Since records were not complete in all cases, we analyzed all available data (collected $n=7,921$, stored $n=$ 2,014 , transplanted $n=36$ ). The CB units were analyzed concerning volume (transplant volume), nucleated (NC), mononucleated (MNC) and CD34+ cells as well as the reasons why collected $\mathrm{CB}$ units did not fulfill storage criteria. $\mathrm{CB}$ units released for transplantation were analyzed concerning the pertinent indications for transplantation, patients' age and transplant center situation. Furthermore, we compared stored versus released $\mathrm{CB}$ units with regard to volume, cell count and ethnic background of the donor in order to reappraise our collection and preparation strategies.

\section{Material and Methods}

\section{Collection of $C B$}

Due to the increase in CB transplantations, German guidelines for the transplantation of stem cells from CB were established in 1999. They are mandatory for storage and release of allogeneic CB transplants in Ger- many and lay down all medical and legal requirements. CB units are classified as medical drugs, and thus the German Pharmaceutical Law (Arzneimittelgesetz; AMG) does apply. Therefore, a manufacturing license and a marketing authorization issued by Regional and Federal Administrative Authorities (Regierungspräsidium and Paul-Ehrlich-Institut) are required. Furthermore, international quality standards such as FACT (Foundation for the Accreditation of Cellular Therapy) have been established and are considered as essential for the worldwide distribution of $\mathrm{CB}$ transplants [11]. In addition to the German guidelines, these standards describe all medical details and cover all relevant aspects of $\mathrm{CB}$ collection, processing, testing, storage, selection and release for transplantation.

As donor selection has to be performed carefully, a detailed medical history of the whole family (including grandparents) is mandatory in order to minimize the potential risk of transmitting unrecognized hereditary diseases. In addition to the German Guidelines for the Collection of Blood and Blood Components (Richtlinien zur Gewinnung von Blut und Blutbestandteilen und zur Anwendung von Blutprodukten (Hämotherapie)), special aspects have to be considered for $\mathrm{CB}$ donation. $\mathrm{CB}$ must not be collected if there are known hereditary diseases affecting hematopoiesis in the family or if there is any evidence of severe disabilities or diseases in the unborn child. Further major exclusion criteria are infectious diseases of the mother that may be transmitted to the child, severe complications during pregnancy, premature delivery, dystrophia (birth weight $<1,500 \mathrm{~g}$ ) or perinatal asphyxia. The mother has to agree on testing for infectious diseases and on HLA typing (child/donor) and furthermore accepts her data to be recorded at the Mannheim Cord Blood Bank (informed consent).

In general the collection of $\mathrm{CB}$ must not affect the delivery and should be performed by continuously trained staff (e.g. midwives and physicians). After the birth of the infant and the placenta still in utero, the umbilical cord is clamped off. A thorough cleaning and disinfection of the umbilical cord is essential in order to prevent contamination with maternal blood or germs. Subsequently, the umbilical cord is punctured under sterile conditions, and thus the blood flows into the collection bag due to gravity. We use a triple bag system which contains citrate phosphate dextrose (CPD) as anticoagulant. After the collection process (requiring only a few minutes), a detailed documentation and labeling of the $\mathrm{CB}$ unit is required before it is stored in a secure temperature-controlled box and subsequently transported to the CB Bank Mannheim by courier. The storage and transport temperature must not fall below or rise above $22 \pm 4^{\circ} \mathrm{C}$.

\section{Testing of $C B$}

Each $\mathrm{CB}$ unit is analyzed for volume, $\mathrm{NC}, \mathrm{MNC}$ and $\mathrm{CD} 34+$ cell count, erythroblasts (stained blood smear), CFU-GM, HLA class I/II antigens, $\mathrm{ABO}$ and Rhesus, parvovirus B19, CMV-PCR (optional) as well as bacterial contamination. Infectious disease testing on maternal blood samples includes HBs antigen, anti-HBc, anti-HIV I/II, anti-HCV, anti-CMV IgG and IgM, TPHA, anti-HTLV I/II, HCV-PCR, HBV-PCR, HIV-PCR and ALT; in addition an indirect antiglobulin testing is performed.

The volume of the $\mathrm{CB}$ is determined by weighing the collection bag (minus tara, $1 \mathrm{~g}$ equates to $0.95 \mathrm{ml} \mathrm{CB}$ ). NC are measured by an automatic cell counter (Cell-Dyn 3200, Abbott Laboratories, Abbott Park, IL, USA), CD34+ cells are determined by flow cytometry (FACSCalibur, BD Biosciences, San Jose, CA, USA) with CD34-PE and CD45FITC (BD Biosciences). Sterility testing is performed using an automated system with aerobic and anaerobic incubation (BacT/Alert, bioMerieux, Nürtingen, Deutschland). Viability is tested by colony-forming unit assays (MethoCult GFH 444, Stemcell Technologies, Vancouver, BC, Canada).

The maternal blood has to be drawn within $\pm 48 \mathrm{~h}$ around the delivery. Back-up samples of maternal blood and CB are stored for future testing at $-70{ }^{\circ} \mathrm{C}$ and $\leq-150{ }^{\circ} \mathrm{C}$ (vapor phase of liquid nitrogen), respectively. 
Table 1. Collection data of $\mathrm{CB}$ units, mean $\pm \mathrm{SD}$, minimum and maximum values

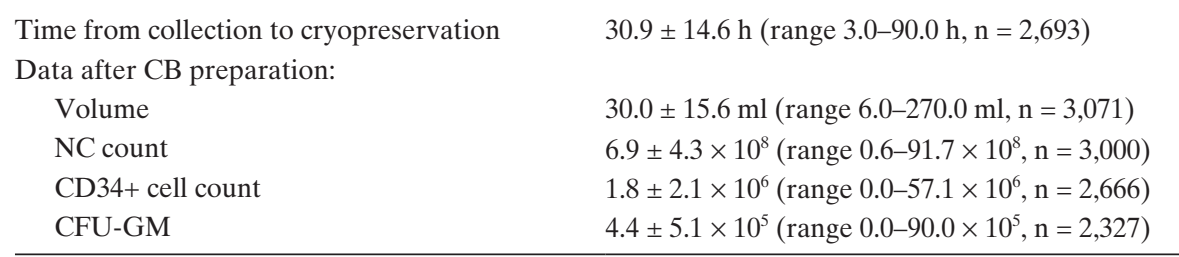

Six months after birth, we request an optional additional maternal blood sample in order to repeat the serological tests and a medical questionnaire addressing the development of the child.

\section{Preparation of $C B$}

According to the German guidelines, the minimum $\mathrm{CB}$ volume before preparation is $60 \mathrm{ml}$, whereas the minimum $\mathrm{NC}$ count after preparation must be $>5 \times 10^{8}$. Furthermore cryopreservation of the $\mathrm{CB}$ unit must be performed within $48 \mathrm{~h}$ after collection (delivery).

Preparation techniques vary considerably amongst different CB banks. However, volume reduction and cryopreservation of the buffy coat is currently considered to be the standard preparation technique worldwide. Major production steps include centrifugation, separation of the buffy coat using an automated device and further preparation in the GMP clean room area. Dimethyl sulfoxide (DMSO) is commonly used as a cryoprotectant. At our center we use autologous CB plasma to prepare the cryoprotectant solution with a DMSO concentration of 5\%. Cryopreserved $\mathrm{CB}$ is then stored at the vapor phase of liquid nitrogen at $\leq-150$ ${ }^{\circ} \mathrm{C}$. Former analysis showed the achievement of high progenitor cell recovery [12]. Once all relevant testing results are available and approved by the head of the production department, the data of the CB units are reported to the ZKRD via the national GERMIS (German Marrow Donor Information System) computer network and are released from quarantine storage.

\section{Statistics}

Statistical differences of cell counts and ethnic background of the donors between released and stored CB units were tested using the MannWhitney test. The level of significance was defined as $\mathrm{p}<0.05$. Statistical analysis was performed using SPSS ${ }^{\circledR} 13.0$ statistical software (SPSS Inc., Chicago, IL, USA).

\section{Results}

\section{Collection Data}

Data on volume, cell count (NC, CD34+ cells) after preparation, time from collection to cryopreservation and viability were collected from all $\mathrm{CB}$ units shipped to the Cord Blood Bank Mannheim that met the preparation criteria (table 1). Mean $( \pm \mathrm{SD})$ values were: time from collection to freezing $30.9 \pm 14.6 \mathrm{~h}$, volume $30.0 \pm 15.6 \mathrm{ml}, \mathrm{NC}$ count $6.9 \pm 4.3 \times$ $10^{8}$, CD $34+$ cell count $1.8 \pm 2.1 \times 10^{6}$ and CFU-GM $4.4 \pm$ $5.1 \times 10^{5}$.

\section{Exclusion Criteria}

Since there are various reasons for the exclusion of collected $\mathrm{CB}$ units from further processing, only $25 \%$ of all $\mathrm{CB}$ units are finally stored at the Mannheim CB bank (table 2). The main reasons for exclusion are i) insufficient collection vol-
Table 2. Reasons for the exclusion of collected CB units (collected $\mathrm{n}=7,921$, stored $\mathrm{n}=2,014 ; 25 \%$ )

\begin{tabular}{lc}
\hline Exclusion criteria & $\%$ \\
\hline Volume $<68 \mathrm{ml}$ & 57.7 \\
Storage/transport time $>48 \mathrm{~h}$ & 19.2 \\
Nucleated cell count $<5 \times 10^{8}$ & 7.2 \\
Problems during preparation $(\mathrm{e} . \mathrm{g}$. leakage of collection bag, & 3.9 \\
$\quad$ breakage of collection bag during centrifugation, clot) & \\
Wrong/incomplete documentation in hospital & 3.4 \\
Medical history & 3.2 \\
Abnormal maternal infectious disease testing & 2.4 \\
Abnormal sterility testing & 1.4 \\
Transport temperature $<18{ }^{\circ} \mathrm{C}$ or $>26^{\circ} \mathrm{C}$ & 1.1 \\
Insufficient CFU-GM & 0.5 \\
\hline
\end{tabular}

Table 3. Countries of the patients / transplant centers who received transplants from the Mannheim CB bank

\begin{tabular}{lrr}
\hline Countries & $\mathrm{n}$ & $\%$ \\
\hline USA & 12 & 32 \\
France & 10 & 28 \\
Spain & 4 & 11 \\
Canada & 3 & 8 \\
UK & 2 & 6 \\
Czech Republic & 1 & 3 \\
Poland & 1 & 3 \\
Greece & 1 & 3 \\
Israel & 1 & 3 \\
Iran & 1 & 3 \\
Total & 36 & 100 \\
\hline
\end{tabular}

ume, ii) delayed arrival at the processing site, iii) $\mathrm{NC}$ count $<5 \times 10^{8}$, i.v.) loss during preparation and v) wrong or incomplete documentation and labeling at the maternity unit.

\section{Patient Data}

Until now, 36 Mannheim CB units have been released for transplantation worldwide since 1998. Transplant centers that received $\mathrm{CB}$ units from Mannheim were mainly located in North America and Europe (table 3). In Europe, the majority of $\mathrm{CB}$ units were sent to France which reflects the experiences of $\mathrm{CB}$ transplantation in this country. So far, no $\mathrm{CB}$ unit from the CB Bank Mannheim has been shipped to a German transplant center. 
Fig. 1. Age of patients who received a Mannheim CB unit $(\mathrm{n}=36)$.

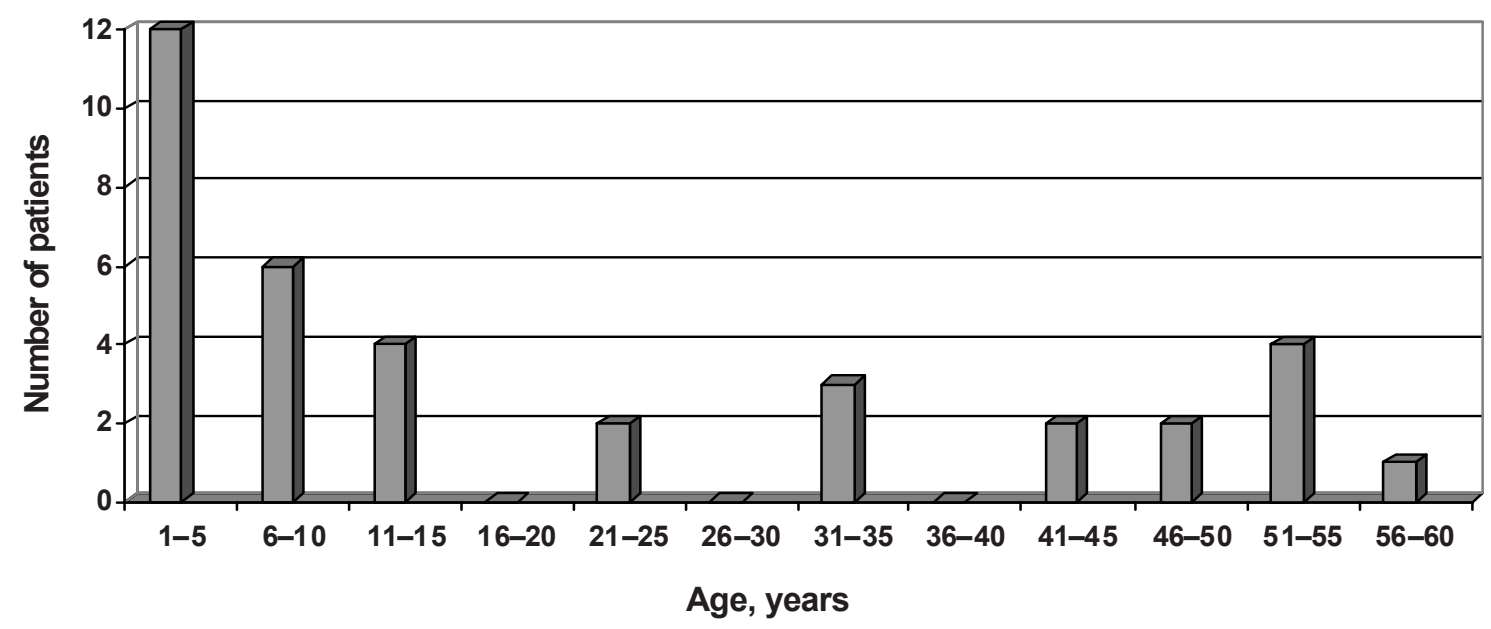

The analysis of patients' age showed that $62 \%$ of the recipients were children under 15 years of age (fig. 1), the mean age of all patientswas 20 years.

In addition, we evaluated transplantation indications (fig. 2). Most patients suffered from hematological malignancies, primarily from acute leukemias, non-malignant hematological diseases, immune deficiencies and metabolic diseases. However, in $11 \%$ of all cases, we did not get any information about the recipients' underlying disease from the transplant center (table 4). In Germany, CB banks are obliged to report in detail to the Paul-Ehrlich-Institut about the clinical outcome after transplantation. Hence medical questionnaires are sent to the transplant centers at certain intervals. However, feedback is limited, and thus our analysis is incomplete.

\section{Comparison of Transplanted Units with Stored CB Units}

We compared transplanted $\mathrm{CB}$ units to the pool of all stored $\mathrm{CB}$ concerning cell count (NC, MNC, CD34+ cells) and volume after preparation. Transplanted $\mathrm{CB}$ units showed significantly higher cell counts for NC, MNC and CD34+ cells (fig. 2) and had a larger volume after preparation $(33.5 \pm 17.6 \mathrm{ml}$ $(\mathrm{n}=36)$ vs. $30.2 \pm 15.6 \mathrm{ml}(\mathrm{n}=1,999) ; \mathrm{p}=0.006)$.

Correlating cell counts to the patient's body weight $(\mathrm{BW})$ revealed a mean cell dose of $5.5 \times 10^{7} \mathrm{NC} / \mathrm{kg} \mathrm{BW}(\mathrm{n}=29$, median $3.2 \times 10^{7} \mathrm{NC} / \mathrm{kg} \mathrm{BW}$, min. $0.6 \times 10^{7} \mathrm{NC} / \mathrm{kg} \mathrm{BW}$, max. 27.0 $\left.\times 10^{7} \mathrm{NC} / \mathrm{kg} \mathrm{BW}\right)$ and a mean CD34+ cell dose of $1.5 \times 10^{5}$ $\mathrm{CD} 34+/ \mathrm{kg} \mathrm{BW}\left(\mathrm{n}=29\right.$, median $0.9 \times 10^{5} \mathrm{CD} 34+$ cells $/ \mathrm{kg} \mathrm{BW}$, min. $0.08 \times 10^{5} \mathrm{CD} 34+$ cells $/ \mathrm{kg}$ BW, max. $8.6 \times 10^{5} \mathrm{CD} 34+$ cells $/ \mathrm{kg} \mathrm{BW}$ ). Pursuant to international transplantation standards, a minimum NC dose of $2.5 \times 10^{7} \mathrm{NC} / \mathrm{kg} \mathrm{BW}$ and a minimum CD34+ cell dose of $2.0 \times 10^{5} \mathrm{CD} 34+$ cells $/ \mathrm{kg} \mathrm{BW}$ is required to expect a successful transplantation $[13,14]$.

Unfortunately, we did not receive reliable information in all cases as to whether units were part of a single or multiple transplant.
Table 4. Diseases of patients who received a Mannheim CB unit

\begin{tabular}{lrc}
\hline Disease & $\mathrm{n}$ & $\%$ \\
\hline Hematologic & 27 & 73 \\
AML & 8 & 21 \\
ALL & 8 & 21 \\
NHL & 6 & 17 \\
CML & 3 & 8 \\
Fanconi's anemia & 1 & 3 \\
HLH & 1 & 3 \\
Immune deficiency & 3 & 9 \\
SCID & 1 & 3 \\
Wiskott-Aldrich syndrome & 2 & 6 \\
Metabolic/accumulation & 2 & 6 \\
Hurler's disease & 1 & 3 \\
Osteopetrosis & 1 & 3 \\
No information & 4 & 11 \\
\cline { 2 - 3 } Total & 36 & 100
\end{tabular}

$\mathrm{AML}=$ Acute myeloid leukemia; $\mathrm{ALL}=$ acute lymphocytic leukemia; $\mathrm{NHL}=$ non-Hodgkin's lymphoma; $\mathrm{CML}=$ chronic myelogenous leukemia; HLH = hemophagocytic lymphohistiocytosis; SCID = severe combined immunodeficiency.

\section{Ethnic Background}

CB transplants are an important alternative, particularly for patients who cannot be provided with PBSC or stem cells from bone marrow because of their infrequent HLA type. Those patients are often immigrants or persons with a mixed ethnic background $[15,16]$. We therefore analyzed the ethnic background of the donor parents. We compared the percentage of donors with an ethnic minority background among transplanted versus stored $\mathrm{CB}$ units. Among the transplanted $\mathrm{CB}$ units we found significantly $(\mathrm{p}=0.04)$ more donors from ethnic minorities (mother and/or father of the infant donor): 36 versus $20 \%$ ( $n=150$ randomly selected stored units). 


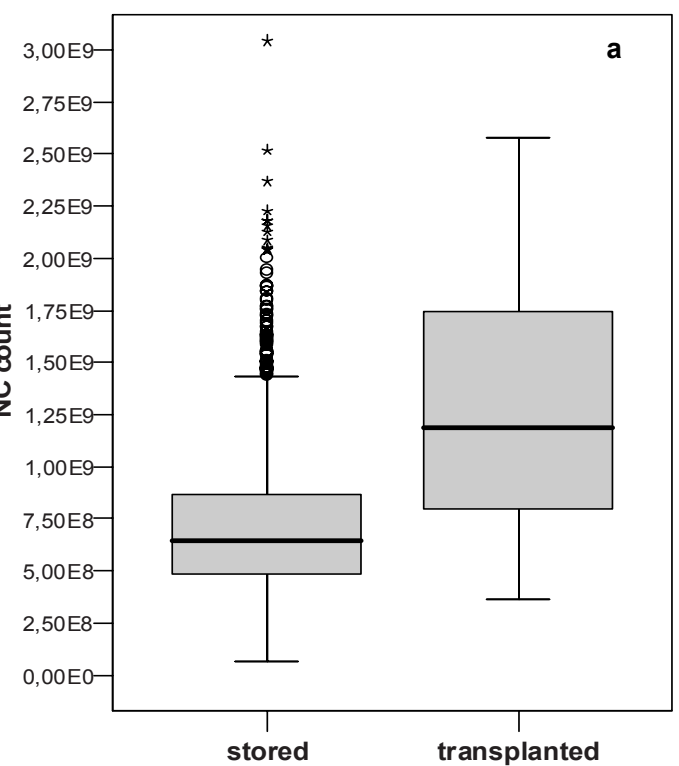

\begin{tabular}{|c|c|c|}
\hline & Stored & Transplanted \\
\hline $\mathrm{n}$ & 1,989 & 36 \\
\hline \multicolumn{3}{|l|}{$\mathrm{NC} \times 10^{8}$} \\
\hline Min. & 0.7 & 3.6 \\
\hline Max. & 90.7 & 25.8 \\
\hline Mean & 7.2 & 12.5 \\
\hline Median & 6.5 & 11.9 \\
\hline $\mathrm{SD}$ & 4.2 & 5.7 \\
\hline $\mathrm{p}$ & \multicolumn{2}{|c|}{$<0.001$} \\
\hline
\end{tabular}

Fig. 2. Comparison of cell counts between stored and transplanted CB units. a $\mathrm{NC}$ count, b $\mathrm{MNC}$ count, c CD34+ cell count.

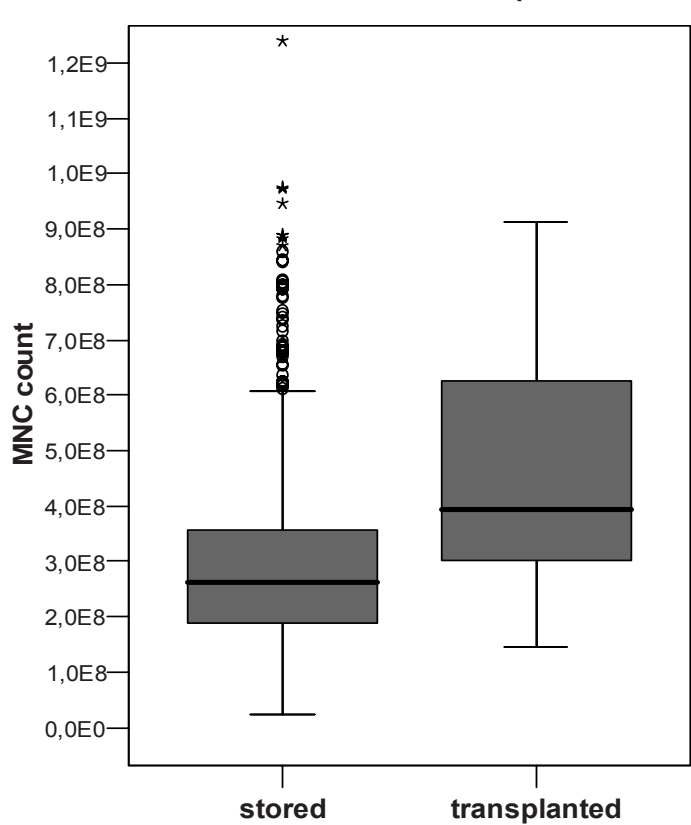

\begin{tabular}{|c|c|c|}
\hline & Stored & Transplanted \\
\hline $\mathrm{n}$ & 1,978 & 36 \\
\hline \multicolumn{3}{|l|}{$\mathrm{MNC}+\times 10^{8}$} \\
\hline Min. & 0.2 & 1.4 \\
\hline Max. & 35.5 & 9.1 \\
\hline Mean & 2.9 & 4.7 \\
\hline Median & 2.6 & 4.0 \\
\hline SD & 1.7 & 2.2 \\
\hline $\mathrm{p}$ & & \\
\hline
\end{tabular}

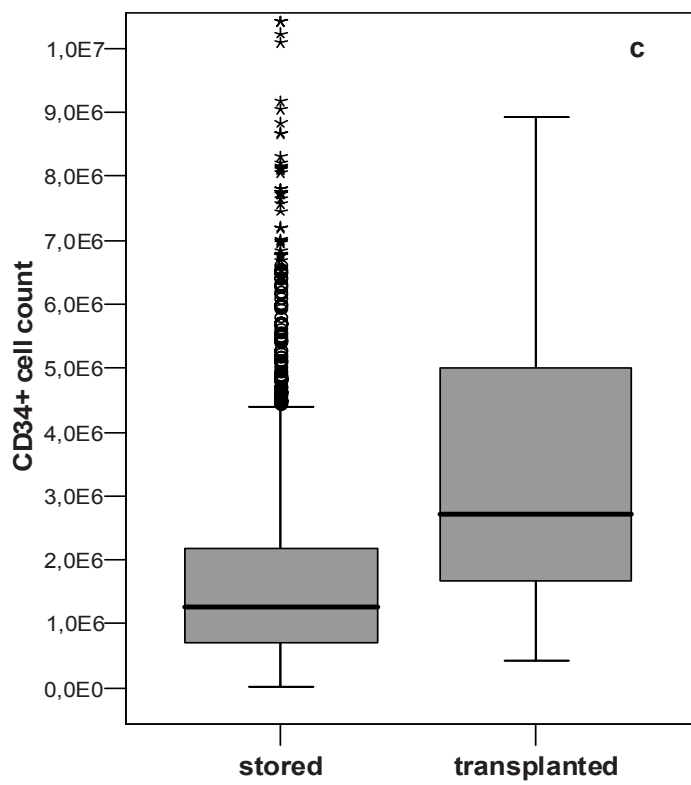

\begin{tabular}{|c|c|c|}
\hline & Stored & Transplanted \\
\hline $\mathrm{n}$ & 1,966 & 36 \\
\hline \multicolumn{3}{|c|}{$\mathrm{CD} 34+\times 10^{6}$} \\
\hline Min. & 0.02 & 0.4 \\
\hline Max. & 57.1 & 8.9 \\
\hline Mean & 1.8 & 3.3 \\
\hline Median & 1.3 & 2.7 \\
\hline SD & 2.1 & 2.2 \\
\hline $\mathrm{p}$ & \multicolumn{2}{|c|}{$<0.001$} \\
\hline
\end{tabular}




\section{Discussion}

$\mathrm{CB}$ is a valuable source of hematopoietic stem cells that is successfully applied for allogeneic transplantation. More than 6,000 unrelated CB transplantations to treat malignant and non-malignant diseases have been performed since the first CB transplant in 1988. In accordance with recent publications our data confirm that main indications for CB transplantations are malignant diseases (acute myeloid leukemia (AML); chronic myelogenous leukemia (CML); non-Hodgkin's lymphoma (NHL); ) and non-malignant hematologic and metabolic diseases as well as immune deficiencies [2, 3, $13,17,18]$. Although our CB units were mainly used for children, $\mathrm{CB}$ is becoming increasingly relevant for the transplantation of adult patients too [5, 19-21]. We assume when Mannheim CB units were used for the transplantation of adults, they were part of a double transplant. According to the latest Eurocord data, since 2006 the majority of CB units is now being used for the transplantation of adults instead of children. CB offers several advantages. Firstly it is available in great quantities and can be stored for more than a decade (145 months at our center). Secondly, it can be easily obtained since it does not interfere with the delivery and does not cause any risk for the mother or the infant donor. Thirdly, in contrast to bone marrow or PBSC, CB units are already tested and characterized in detail when reported to the registry. Thus, they are immediately available, which is especially important for high-risk patients in urgent need of a transplant or for patients who cannot be provided with a bone marrowor PBSC-derived transplant. Fourthly, CB seems to have immunological advantages, as transplant data show, in that there is a lower incidence of and less severe graft-versus-host disease compared to bone marrow or PBSC. There is increasing evidence that this may be due to the immune immaturity of the infant cells [22-25]. In line with this, several studies proved that the clinical outcomes of HLA-mismatched CB transplantations are comparable to fully HLA-matched bone marrow or PBSC transplantations [5, 23, 26]. Furthermore, it was shown that HLA disparities can be compensated by transplanting a higher cell dosage [14, 27]. Fifthly, CB transplants are considered to have a lower risk of transmitting viruses to the patient [14].

However, there are some considerable limitations. As the donor is an infant, certain congenital or genetic diseases may not have been detected at the time of birth. A second collection of stem cells or additional donor lymphocytes will not be possible. Additionally, the amount of CD34+ cells is restricted due to the relatively small collection volume.

As our data confirm, the eligibility of collected CB is often limited by little volume and small NC count as well, as only $25 \%$ of all collected CB units fulfilled storage criteria. In our experience, the time of clamping the cord is crucial for the collection volume. Since this span of time varies among hospitals and midwifes/physicians, the success of additional training in order to increase the collection volume is limited. Nevertheless, to maximize the volume of $\mathrm{CB}$, continuous training of collecting staff is essential. Therefore, a close contact between hospital staff and the CB bank including discussion of problems is necessary.According to the German guidelines for the transplantation of stem cells from $\mathrm{CB}$, a minimum collection volume of $60 \mathrm{ml}$ is required for suitable $\mathrm{CB}$ units (cut-off value at the Cord Blood Bank Mannheim: $68 \mathrm{ml}$ including 8 $\mathrm{ml}$ for diagnostic purposes). Since the number of double cord transplantations is increasing constantly, the demand for smaller CB units might also grow, especially in case of a rare HLA type. Thus the requirement of the German guidelines should be discussed and adapted to the new developments in clinical transplantation. A considerable reduction of the high exclusion rate will also help to improve the motivation of collecting staff and parents. However, until now our data show that mainly the large volume and high $\mathrm{NC}$ count units are transplanted.

In several countries, e.g. in the USA or the UK, public CB banks employ their own staff performing $\mathrm{CB}$ collections and documentation on-site. This seems to be an effective strategy to support midwifes and physicians; however, under these conditions $\mathrm{CB}$ collection is not possible during nights and weekends.

The development of new technical devices, e.g. vacuum systems, could become a valuable tool to improve cell yield. Increasing volume and cell count would minimize the percentage of excluded $\mathrm{CB}$ units and thus considerably increase the number of stored CB units.

Interestingly, we found a comparably low bacterial contamination $[28,29]$. Even though no further details were given in the mentioned publications, we assume that a thorough cleaning and disinfection protocol of the cord could explain these results.

As mentioned above, a current strategy to overcome the low cell count in adult transplantation is to use two $\mathrm{CB}$ units rather than one which was performed for the first time in 2005 $[30,31]$. A higher dose of NC might result in a shorter engraftment period, minimizing the risk for infections and other complications [6, 32], while the HLA genotype types of the different units do not need to be identical. This has become the standard protocol in adult $\mathrm{CB}$ transplantations, especially in the USA. However, the minimum $\mathrm{NC}$ dose per $\mathrm{CB}$ per $\mathrm{kg}$ BW should not be less than $1.5 \times 10^{7} \mathrm{NC}$ [31].

Even though cell count and volume are key parameters for the eligibility of $\mathrm{CB}$ units, our data indicate that the ethnic background of the donor also plays a major role. An evaluation of the donors of the 36 transplanted Mannheim CB units showed an ethnic minority background or a mixed ethnic background in $36 \%$ compared with only $20 \%$ in the stored units. A major advantage of $\mathrm{CB}$ is the possibility to collect and store selected units with potential rare HLA types from ethnic minorities. Those donors are underrepresented in the pool of registered bone marrow or stem cell donors which ac- 
counts for a lack of certain HLA genotypes [15]. It is often impossible to find a matching donor for patients with a mixed ethnic background. Thus CB offers an important alternative source of hematopoietic stem cells. Our data indicate that more CB units from ethnic minorities are needed. Therefore, a directed recruitment of those donors would be reasonable.

In several countries, the value of $\mathrm{CB}$ has been recognized by the government, and efforts have been taken in order to build up national inventories. In the USA, the Stem Cell Therapeutic and Research Act of 2005 provides federal funding for $\mathrm{CB}$ banks that collect and register $\mathrm{CB}$ units for public use. An interim target is to set up an US inventory of 150,000 public $\mathrm{CB}$ units. Unfortunately, in Germany, no such objectives concerning public CB banks have been set yet. Additional support by the government would be important to initiate a national program for the benefit of the public. From our recent experiences, there is tremendous public interest in allogeneic $\mathrm{CB}$ donation, since $\mathrm{CB}$ storage for autologous use (commercial $\mathrm{CB}$ banking) does not appeal all parents. We therefore suggest information campaigns to address the public in an objective manner and to attract more potential donors especially from ethnic minorities and mixed ethnic minority donors.

In summary, $\mathrm{CB}$ offers an alternative treatment for children and adults in allogeneic transplantation. Its eligibility is still limited by insufficient volume and/or cell count. Therefore, more high-quality $\mathrm{CB}$ units that fulfill international standards are required, especially from ethnic minorities or mixed ethnic minority donors. The pool of potential transplants has to be increased. Furthermore, CB units with a high cell count as well as units from ethnic minorities are highly requested. Collection of $\mathrm{CB}$ from ethnic minorities is therefore a promising strategy to improve donor search for those patients that cannot be provided with a matching donor from the established registries.

\section{Disclosure}

The authors declared no conflict of interest.

\section{References}

1 Hwang WY, Samuel M, Tan D, Koh LP, Lim W, Linn YC: A meta-analysis of unrelated donor umbilical cord blood transplantation versus unrelated donor bone marrow transplantation in adult and pediatric patients. Biol Blood Marrow Transplant 2007;13:444-453.

2 Frangoul H, Wang L, Harrell FE Jr, Manes B, Calder C, Domm J: Unrelated umbilical cord blood transplantation in children with immune deficiency: results of a multicenter study. Bone Marrow Transplant 2010;45:283-288.

$\checkmark 3$ Prasad VK, Mendizabal A, Parikh SH, Szabolcs P, Driscoll TA, Page K, Lakshminarayanan S, Allison J, Wood S, Semmel D, Escolar ML, Martin PL, Carter S, Kurtzberg J: Unrelated donor umbilical cord blood transplantation for inherited metabolic disorders in 159 pediatric patients from a single center: influence of cellular composition of the graft on transplantation outcomes. Blood 2008;112:2979-2989.

4 Eapen M, Rubinstein P, Zhang MJ, Stevens C, Kurtzberg J, Scaradavou A, Loberiza FR, Champlin RE, Klein JP, Horowitz MM, Wagner JE: Outcomes of transplantation of unrelated donor umbilical cord blood and bone marrow in children with acute leukaemia: a comparison study. Lancet 2007 369:1947-1954.

5 Laughlin MJ, Eapen M, Rubinstein P, Wagner JE, Zhang MJ, Champlin RE, Stevens C, Barker JN, Gale RP, Lazarus HM, Marks DI, van Rood JJ, Scaradavou A, Horowitz MM: Outcomes after transplantation of cord blood or bone marrow from unrelated donors in adults with leukemia. N Engl J Med 2004;351:2265-2275.

6 Wagner JE, Barker JN, DeFor TE, Baker KS, Blazar BR, Eide C, Goldman A, Kersey J, Krivit W, MacMillan ML, Orchard PJ, Peters C, Weisdorf DJ, Ramsay NK, Davies SM: Transplantation of unrelated donor umbilical cord blood in 102 patients with malignant and nonmalignant diseases: influence of CD34 cell dose and HLA disparity on treatment-related mortality and survival. Blood 2002;100:1611-1618.
7 Johansen KA, Schneider JF, McCaffree MA, Woods GL: Efforts of the United States' national marrow donor program and registry to improve utilization and representation of minority donors. Transfus Med 2008;18:250-259.

8 Barker JN, Krepski TP, DeFor TE, Davies SM, Wagner JE, Weisdorf DJ: Searching for unrelated donor hematopoietic stem cells: availability and speed of umbilical cord blood versus bone marrow. Biol Blood Marrow Transplant 2002;8:257-260.

$\checkmark 9$ Rocha V, Kabbara N, Ionescu I, Ruggeri A, Purtill D, Gluckman E: Pediatric related and unrelated cord blood transplantation for malignant diseases. Bone Marrow Transplant 2009;44:653-659.

10 Gluckman E: History of cord blood transplantation. Bone Marrow Transplant 2009;44:621-626.

11 NetCord-FACT: International Standards for Cord Blood Collection, Processing, Testing, Banking, Selection and Release, 4rd ed.Omaha, FACT, 2008. http://factwebsite.org/uploadedFiles/ News/4th_Edition_Cord_Blood_Standards_4.0.pdf. 12 Eichler H, Meckies J, Schmut N, Kern S, Klüter H, Zieger W: Präparative und arzneimittelrechtliche Aspekte bei der Sammlung von Stammzellpräparaten aus Plazentarestblut. Z Geburtshilfe Neonatol 2001;205:218-223.

13 Ljungman P, Bregni M, Brune M, Cornelissen J, Witte TD, Dini G, Einsele H, Gaspar HB, Gratwohl A, Passweg J, Peters C, Rocha V, Saccardi R, Schouten H, Sureda A, Tichelli A, Velardi A, Niederwieser D: Allogeneic and autologous transplantation for haematological diseases, solid tumours and immune disorders: current practice in europe 2009. Bone Marrow Transplant 2010;45:219-234.

14 Gluckman E, Rocha V: Donor selection for unrelated cord blood transplants. Curr Opin Immunol 2006;18:565-570.

15 Davey S, Armitage S, Rocha V, Garnier F, Brown J, Brown CJ, Warwick R, Fehily D, Watt S, Gluckman E, Vora A, Contreras M, Navarrete CV: The London Cord Blood Bank: analysis of banking and transplantation outcome. Br J Haematol 2004;125:358-365.
16 Querol S, Mufti GJ, Marsh SG, Pagliuca A, Little AM, Shaw BE, Jeffery R, Garcia J, Goldman JM, Madrigal JA: Cord blood stem cells for hematopoietic stem cell transplantation in the UK: how big should the bank be? Haematologica 2009;94:536-541.

17 Moise KJ Jr: Umbilical cord stem cells. Obstet Gynecol 2005;106:1393-1407.

18 Brunstein CG, Setubal DC, Wagner JE: Expanding the role of umbilical cord blood transplantation. $\mathrm{B}$ J Haematol 2007;137:20-35.

19 Atsuta Y, Suzuki R, Nagamura-Inoue T, Taniguchi S, Takahashi S, Kai S, Sakamaki H, Kouzai Y, Kasa M, Fukuda T, Azuma H, Takanashi M, Okamoto S, Tsuchida M, Kawa K, Morishima Y, Kodera Y, Kato S: Disease-specific analyses of unrelated cord blood transplantation compared with unrelated bone marrow transplantation in adult patients with acute leukemia. Blood 2009;113:1631-1638.

20 Brunstein CG, Wagner JE: Cord blood transplantation for adults. Vox Sang 2006;91:195-205.

21 Rocha V, Labopin M, Sanz G, Arcese W, Schwerdtfeger R, Bosi A, Jacobsen N, Ruutu T, de Lima M, Finke J, Frassoni F, Gluckman E: Transplants of umbilical-cord blood or bone marrow from unrelated donors in adults with acute leukemia. N Engl J Med 2004;351:2276-2285.

22 Wagner JE, Kernan NA, Steinbuch M, Broxmeyer HE, Gluckman E: Allogeneic sibling umbilical-cordblood transplantation in children with malignant and non-malignant disease. Lancet 1995;346:214-219.

23 Rocha V, Cornish J, Sievers EL, Filipovich A, Locatelli F, Peters C, Remberger M, Michel G, Arcese W, Dallorso S, Tiedemann K, Busca A, Chan KW, Kato S, Ortega J, Vowels M, Zander A, Souillet G, Oakill A, Woolfrey A, Pay AL, Green A, Garnier F, Ionescu I, Wernet P, Sirchia G, Rubinstein P, Chevret S, Gluckman E: Comparison of outcomes of unrelated bone marrow and umbilical cord blood transplants in children with acute leukemia. Blood 2001;97:2962-2971. 
24 Rocha V, Wagner JE Jr, Sobocinski KA, Klein JP, Zhang MJ, Horowitz MM, Gluckman E: Graftversus-host disease in children who have received a cord-blood or bone marrow transplant from an HLA-identical sibling. Eurocord and Internationa Bone Marrow Transplant Registry Working Committee on Alternative Donor and Stem Cell Sources. N Engl J Med 2000;342:1846-1854.

25 Kurtzberg J, Graham M, Casey J, Olson J, Stevens CE, Rubinstein P: The use of umbilical cord blood in mismatched related and unrelated hemopoietic stem cell transplantation. Blood Cells 1994;20:275283.

26 Sanz MA: Cord-blood transplantation in patients with leukemia - a real alternative for adults. N Engl J Med 2004;351:2328-2330.

27 Rubinstein P SC, Kurtzberg J, Eapen M, Stevens C, Scaradavou A, Klein J, Horowitz M, Wagner J: Unrelated donor hematopoietic stem cell transplantation (HSCT) in children with acute leukemia: risks and benefits of umbilical cord blood (CB) vs. Bone marrow (BM). Blood 2005;106:abstract 302 .

28 Ademokun JA, Chapman C, Dunn J, Lander D, Mair K, Proctor SJ, Dickinson AM: Umbilical cord blood collection and separation for haematopoietic progenitor cell banking. Bone Marrow Transplant 1997;19:1023-1028.

-29 Meyer TP, Hofmann B, Zaisserer J, Jacobs VR, Fuchs B, Rapp S, Weinauer F, Burkhart J: Analysis and cryopreservation of hematopoietic stem and progenitor cells from umbilical cord blood. Cytotherapy 2006;8:265-276.

30 Barker JN, Weisdorf DJ, DeFor TE, Blazar BR, McGlave PB, Miller JS, Verfaillie CM, Wagner JE: Transplantation of 2 partially HLA-matched umbilical cord blood units to enhance engraftment in adults with hematologic malignancy. Blood 2005;105:1343-1347.

-31 Majhail NS, Brunstein CG, Wagner JE: Double umbilical cord blood transplantation. Curr Opin Immunol 2006;18:571-575.

- 32 Gluckman E, Rocha V, Boyer-Chammard A, Locatelli F, Arcese W, Pasquini R, Ortega J, Souillet G, Ferreira E, Laporte JP, Fernandez M, Chastang C: Outcome of cord-blood transplantation from related and unrelated donors. Eurocord Transplant Group and the European Blood And Marrow Transplantation Group. N Engl J Med 1997;337:373-381. 